\title{
A Comparison of the Digestibility of 'Two Complete Rations Containing Either Raw or Alkali-Treated Sugarcane Bagasse ${ }^{1}$
}

\author{
Paul F. Randel ${ }^{2}$ \\ INTRODUCTION
}

Little information is available concerning the digestibility of complete rations in which sugarcane bagasse is the source of fiber. Prieto and Randel (7) used a chromic oxide-indicator method with eight lactating cows to determine digestion coefficients for a ration containing 15-percent crude bagasse and 85-percent concentrates. Though feeding trials to evaluate bagasse treated with sodium hydroxide have been in progress at this station for several years (\$), there are no previous reports on the digestibility of such rations. The cellulose digestibility of bagalsse, determined by a nylonbag suspension technique, was found to increase substantially with treatment of the raw bagasse in a 2-percent $\mathrm{NaOH}$ solution for 24 hours at ambient temperature (Carrero, R., personal communication). The present experiment was undertaken to compare the in vivo digestibility of complete rations alike in all respects, except that one contained raw and the other alkali-treated bagasse.

\section{EXPERIMENTAL PROCEDURE}

Two successive digestibility trials were conducted during the autumn of 1970, the same four Holstein steers were used in both. These animals, designated henceforth as 1,2,3, and 4, weighed 316, 242, 261, and $226 \mathrm{~kg}$. (average $261 \mathrm{~kg}$.), respectively, at the start. Slight liveweight gains of 10 , 8,1 , and $8 \mathrm{~kg}$. were recorded for the four stecrs during the course of this 6-week study.

The percentage formula of both rations was: Ground shelled corn, 18.45; ground dried bagasse (raw or treated), 40.00; sugarcane molasses, 27.00;

1 Manuscript submitted to Editorial Board June 1, 1971.

2 Animal Nutritionist, Agricultural Experiment Station, Mayagüez Campus, University of Puerto Rico, Lajas Substation, Lajas, P.R. The author is grateful for the help rendered by Mr. Santos Noel Caraballo, of the Lajas Substation, in the task of making fecal collections; by the Central Analytical Laboratory, Río Piedras, in determining proximate composition of the feed and feces samples; by Mr. Roberto Carrero, of the Industrial Research Laboratory, Puerto IRico Economic Development Administration, Hato Rey, in supplying the alkali-treated bagasse used in this study; and by Dr. P. J. Van Soest, of Cornell University, in performing analyses on the chemical composition and in vitro digestibility of bagasse and bagasse complete rations. 
tunafish meal, 10.00; urea, 2.50; phosphate (mono- and dicalcium), 1.00; salt, 1.00; and vitamin supplement $(6,600,000 \mathrm{IU}$ of $\mathrm{A}, 440,000 \mathrm{IU}$ of D-3, and 22,000 IU of $\mathrm{E}$ per $\mathrm{kg}$.), 0.05. The chemical treatment consisted of soaking the bagasse in a 2-percent $\mathrm{NaOH}$ solution at ambient temperature and pressure for 24 hours. Thereafter it was washed with running water and sun-dried. The raw bagasse had been stored unprotected outdoors in relatively low mounds for several months before being dried for use in this experiment. Molasses was added mechanically to the rations in the final step after the mixer.

The treated-bagasse ration was fed first. For 2 weeks the animals were offered the ration free choice in two daily portions to determine the maximum voluntary consumptions, after which the steers were reweighed. The lowest maximum consumption was approximately $121 \mathrm{~g}$. per lig. of metabolic body weight (3). Eighty percent of this figure, or $97 \mathrm{~g}$. of ration per unit of metabolic weight, was adopted as the fixed amount to be fed to all four animals throughout the rest of the study. The amount of ration offered daily was $6.7,5.1,5.6$, and $5.2 \mathrm{~kg}$. for steers 1 through 4 , respectively. Consumption was complete at this level and there were no instances of feed refusal. Water was given to the animals by bucket twice daily. The animals were maintained in elevated metabolism stalls throughout the

TABLE 1.-Percenlage chemical composition ${ }^{1}$ of the rations and of the feces collecled from each individual sleer

\begin{tabular}{|c|c|c|c|c|c|c|c|}
\hline & DM & CP & EE: & $\mathrm{CF}$ & Ash & NFE & $\begin{array}{l}\text { Calo- } \\
\text { ries" }\end{array}$ \\
\hline \multicolumn{8}{|c|}{ First trial } \\
\hline Treated-bagasse ration & 85.8 & 19.8 & 2.2 & 19.0 & 14.5 & 44.5 & 3.76 \\
\hline \multicolumn{8}{|l|}{ Feces } \\
\hline Steer No. 1 & 24.4 & 12.0 & 0.8 & 18.6 & 34.0 & 34.6 & 3.17 \\
\hline Steer No. 2 & 28.8 & 13.2 & 1.0 & 19.0 & 36.1 & 30.7 & 3.15 \\
\hline Steer No. 3 & 26.1 & 12.0 & 1.0 & 20.0 & 34.3 & 32.7 & 3.10 \\
\hline Steer No. 4 & 25.3 & 13.9 & 1.0 & 20.1 & 35.7 & 29.3 & 3.01 \\
\hline
\end{tabular}

Second trial

\begin{tabular}{llllllll}
\hline Raw-bagasse ration & 85.4 & 18.1 & 2.3 & 14.2 & 13.8 & 51.6 & 3.85 \\
Feces & & & & & & & \\
Steer No. 1 & 22.5 & 12.6 & 0.7 & 20.4 & 25.8 & 40.5 & 3.51 \\
Steer No. 2 & 26.2 & 11.2 & 0.8 & 20.1 & 26.6 & 41.2 & 3.52 \\
Stecr No. 3 & 23.5 & 12.2 & 0.9 & 19.7 & 26.4 & 40.8 & 3.59 \\
Steer No. 4 & 24.1 & 11.3 & 1.1 & 20.2 & 24.8 & 42.6 & 3.65 \\
\hline
\end{tabular}

1 All components, except I)M, expressed on I)M basis.

2 lixpressed as kcal. per g. of DM. 
study, but were taken out of the stalls briefly each day to ensure adequate exercise. A 6-day preliminary feeding period was followed by an 8-day total fecal collection period. The raw-bagasse ration then was employed, and the same procedure repeated.

The feces were collected and placed in a metal container throughout the day and each morning all residues were scraped up and the whole amount transferred to a metal tub for weighing. After weighing the feces were mixed, and a 500-g. sample was placed in a cake pan. The fecal samples were dried for 2 days at $60^{\circ} \mathrm{C}$. and for 1 additional day at $80^{\circ} \mathrm{C}$. and then reweighed for the determination of dry matter percentage. A sample of the ration was taken and composited at cach feeding, commencing 2 days before the start of the feces collection period and ceasing 2 days before the end of the fecal collections. The composite feed samples were dried for 2 days at $80^{\circ} \mathrm{C}$. for dry matter determination. The dried feed and feces samples were ground in a Wiley mill and stored in glass jars until analyzed for proximate composition by A.O.A.C. procedures (1), and for heat of combusion in a Parr Adiabatic Oxygen Bomb Calorimeter (6).

The following abbreviations will be used hereafter to designate the various chemical fractions studied: DM, dry matter; OM, organic matter (dry matter minus ash); CP, crude protein; EE, ether extract; $\mathrm{CF}$, crude fiber; NFE, nitrogen-free-extract; TDN, total digestible nutrients; and DE, digestible energy.

\section{RESULTS AND DISCUSSION}

As shown in table 1, the two rations were quite similar in chemical composition with regard to DM, CP, EE, ash and caloric content. The principal differenees wore in a higher CF and a lower NFE content in the treated-bagasse as compared with the raw-bagasse ration. The feces voided by the animals consuming the treated-bagasse ration had a higher ash and lower NFE and caloric content than the feces produced on the rawbagasse ration (table 1 ).

While DM intake was almost identical in both trials, DM output in feces was considerably higher when the raw-bagasse ration was consumed (table 2). The individual coefficients of apparent digestibility, as well as the standard errors of the means, demonstrate rather uniform values among the animals within wach ration (1able 3). Somewhat more withinration variation was found with the raw bagasse. Notable differences in digestibility between the two rations are obvious. Except in the case of the EE fraction, there is no overlapping of the individual digestion coefficients, i.e., the highest coeffieient obtained with the raw-bagasse ration falls below the lowest value for the treated-bagasse ration. A mean difference between rations of greater than 10-pereent units, in favor of the 
TABLe 2.-Amounts (g.) of DM consumed and eliminaled in the feces by each individual sleer

\begin{tabular}{|c|c|c|c|c|}
\hline & $\begin{array}{l}\text { Steer } \\
\text { No. } 1\end{array}$ & $\begin{array}{l}\text { Steer } \\
\text { No. } 2\end{array}$ & $\begin{array}{l}\text { Steer } \\
\text { No. } 3\end{array}$ & $\begin{array}{l}\text { Steer } \\
\text { No. } 4\end{array}$ \\
\hline \multicolumn{5}{|c|}{ Firsl trial } \\
\hline $\begin{array}{l}\text { Consumption of treated-bagasse } \\
\text { ration }\end{array}$ & 5,749 & 4,376 & 4,805 & 4,462 \\
\hline Elimination in feces & 1,828 & 1,356 & 1,372 & 1,537 \\
\hline \multicolumn{5}{|c|}{ Second trial } \\
\hline $\begin{array}{l}\text { Consumption of raw-bagasse } \\
\text { ration }\end{array}$ & 5,722 & 4,355 & 4,782 & 4,441 \\
\hline Elimination in feces & 2,287 & 1,968 & 2,317 & 1,933 \\
\hline
\end{tabular}

TABLE 3.-Coefficients of apparent digestibility determined in individual sleers and the mean values with their respective slandard errors

\begin{tabular}{|c|c|c|c|c|c|c|}
\hline Component & $\begin{array}{l}\text { Steer } \\
\text { No. } 1\end{array}$ & $\begin{array}{l}\text { Steer } \\
\text { No. } 2\end{array}$ & $\begin{array}{c}\text { Steer } \\
\text { No. } 3\end{array}$ & $\begin{array}{l}\text { Steer } \\
\text { No. } 4\end{array}$ & Mean & $\begin{array}{c}\text { Mean } \\
\text { dif̂́erence }\end{array}$ \\
\hline \multicolumn{7}{|c|}{ First trial (treated-bagasse ration fed) } \\
\hline DM & 68.2 & 69.0 & 71.4 & 66.6 & $68.6 \pm 1.2$ & \\
\hline OM & 75.4 & 76.8 & 78.1 & 74.1 & $76.1 \pm 0.9$ & \\
\hline CP & 80.6 & 79.2 & 82.6 & 75.7 & $79.6 \pm 1.5$ & \\
\hline EE & 88.3 & 85.6 & 87.8 & 83.8 & $86.4 \pm 1.0$ & \\
\hline CF & 69.0 & 69.0 & 70.0 & 63.6 & $67.9 \pm 1.5$ & \\
\hline NFE & 75.3 & 78.6 & 79.0 & 77.3 & $77.6 \pm 0.8$ & \\
\hline TDN & 66.9 & 68.0 & 69.2 & 65.6 & $67.4 \pm 0.8$ & \\
\hline Calories & 73.2 & 74.0 & 76.5 & 72.4 & $74.0 \pm 0.9$ & \\
\hline $\mathrm{DE}^{1}$ & 2.75 & 2.78 & 2.87 & 2.72 & $2.78 \pm 0.03$ & \\
\hline
\end{tabular}

Second trial (raw-bagasse ralion fed)

\begin{tabular}{lcccccc}
\hline DM & 60.0 & 54.8 & 51.6 & 56.5 & $55.7 \pm 1.8$ & $12.9 \pm 2.7^{2}$ \\
OM & 65.6 & 61.5 & 58.6 & 62.1 & $62.0 \pm 1.4$ & $14.1 \pm 2.1^{3}$ \\
CP & 72.0 & 71.9 & 67.2 & 72.8 & $71.0 \pm 1.3$ & $8.6 \pm 2.6^{2}$ \\
EE & 87.8 & 83.0 & 80.9 & 80.4 & $83.0 \pm 1.7$ & $3.4 \pm 1.3$ \\
CF & 42.8 & 36.1 & 32.8 & 38.1 & $37.5 \pm 2.2$ & $30.4 \pm 2.8^{3}$ \\
NFE & 68.7 & 63.9 & 61.7 & 64.1 & $64.6 \pm 1.5$ & $13.0 \pm 2.3^{2}$ \\
TDN & 59.1 & 55.4 & 52.9 & 55.8 & $55.8 \pm 1.3$ & $11.6 \pm 1.8^{3}$ \\
Calories & 63.6 & 58.6 & 54.8 & 58.7 & $58.9 \pm 1.8$ & $15.1 \pm .^{3}$ \\
DE & 2.45 & 2.26 & 2.11 & 2.26 & $2.27 \pm .07$ & $.51 \pm .0^{2}$
\end{tabular}

1 Expressed as Mcal. per kg. of DM.

${ }^{2}$ Mean difference significant at $P<.05$.

${ }^{3}$ Mean difference significant at $P<.01$. 
treated bagasse, was found for all except the EE and CP fractions. These differences were highly significant $(P<.01)$ for OM, CF, TDN and calories; significant $(P<.05)$ for DM, CP, NFE, and DE; and not significant $(P<.05)$ only in the case of EE.

Because bagasse constituted practically the only source of CF in these rations, the coefficient of CF digestibility presented in table 3 represents essentially the digestibility of bagasse fiber. According to these estimates, the CF of the raw bagasse is only slightly more than one-third digestible, while that of the treated bagasse is two-thirds digestible. Thus the chemical treatment of bagasse nearly doubles the CF digestibility. An increase in CF digestibility would logically have a direct effect on the digestion of the $\mathrm{DM}, \mathrm{OM}, \mathrm{DE}$ and TDN fractions, since these include CF as one of their constituents. The significantly $(P<.05)$ higher apparent digestibility of the $\mathrm{CP}$ in the treated-bagasse ration might be due to the passage of less indigestible material through the intestine, resulting in less metabolic fecal nitrogen. Interpretation of the significant $(P<.05)$ increase in NFE digestibility is difficult because of the variable composition of this fraction (2). Since the NFE fraction contains a variable proportion of the lignin, part of the effect of alkali treatment on its digestibility might be due to the elimination or modification of this indigestible constituent.

Although other comparisons of the in vivo digestibility of raw and treated bagasse are not known to the author, Saxena et al. (9) reported that soaking oat straw (previously hammer milled) in a 1.5-percent $\mathrm{NaOH}$ solution increased the percent DM digestibility as determined in goats, from 42 to 60,39 to 58 , and 39 to 55 , when supplemented with soybean meal, urea and diammonium phosphate, respectively. Klopfenstein and Woods (4) found that the coefficients of OMI digestibility of wheat straw without treatment, treated with a 4-percent $\mathrm{NaOH}$ solution, and treated with a 5 -percent solution, were 43.4, 57.6 and 60.4 , respectively, for lambs. Mellenberger et al. (5) reported that treatment with 0.5 percent $-\mathrm{NaOH}$ increased the DII digestibility of aspen sawdust, as estimated in goats by an extrapolation procedure, from 41 to 52 when a high-roughage basal ration was employed and from 31 to 48 when the basal ration consisted entirely of concentrates. Thus, sugarcane bagasse behaves similarly to other lignocellulosic materials by increased digestibility upon treatment with alkali solution. It has been suggested that the principal effect of the alkali treatment is saponification of intermolecular ester bonds of lignin and lignin-cellulose, which results in increased swelling of the treated material in water, and consequently greater penetration by cellulolytic microorganisms (10).

Prieto and Randel (7) found that a complete ration containing 15-percent raw bagasse and 85-percent concentrates was superior to the 40 - 
percent raw bagasse (and 60-percent concentrates) ration of the present study (table 3$)$ in digestibility of DM $(71.9 \pm 2.9$ vs. $55.7 \pm 1.8), \mathrm{OM}$ $(74.3 \pm 1.2$ vs. $62.0 \pm 1.4)$ and $\mathrm{TDN}(72.2 \pm 1.3$ vs. $55.8 \pm 1.3)$. The greater over-all digestibility of the former ration can be attributed largely to its higher percentage content of NFE (66.1 vs. 51.6) and lower content of CF (9.85 vs. 14.2). The former fraction gave digestibilities of $80.7 \pm 0.7$ and $64.6 \pm 1.5$ and the latter $36.6 \pm 4.1$ and $37.5 \pm 2.2$ in the two rations, respectively. The two rations were nearly equal in CP digestibility $(71.3 \pm 1.1$ vs. $71.0 \pm 1.3)$, while the only difference in favor of the 40-percent raw bagasse ration was for the proportionately small EE fraction $(70.0 \pm 4.5$ vs. $83.0 \pm 1.7)$. Thus, increasing the raw bagasse content from 15 to 40 percent results in a complete ration of decidedly lower digestibility and energy value. When alkali-treated bagasse is substituted for the raw product, however, it can be used at the 40-percent level without creating an energy-poor ration.

Samples of the two complete rations and of the two classes of bagasse were taken 3 and 5 months, respectively, after the conclusion of this work (another experiment still in progress employing these same rations) and sent to Cornell University for analysis $(11,12)$. The contents of several chemical components, including neutral detergent fiber (NDF) and acid detergent fiber (ADF), as well as in vitro digestibilities found in these samples are presented in table 4 . The alkali treatment resulted in bagasse with increased NDF (cell-wall components) and ADF (lignocellulose); the latter must signify increased cellulose content, as the percentage of lignin remained essentially the same. The treated bagasse contained less acid-detergent solubles (26.2 vs. 17.6 percent), which consist of hemicellulose and cell-wall nitrogen. The latter also was reflected in a lower CP content. An undesirably high silica content in the raw bagasse, due principally to contamination with soil, was removed effectively by the alkali bath and subsequent washing. The effect of the alkali treatment on the estimated DM digestibility of the bagasse was a 62 -percent increase (31.9

TABLE 4.-Percenlage chemical composition and estimated in vitro DM digestibility of bagasse alone and bagasse complete rations

\begin{tabular}{lrrrrrr}
\hline & NDF & ADF & Lignin & Silica & CP $\begin{array}{c}\text { Estimated } \\
\text { in vitro } \\
\text { digesti- } \\
\text { bility }\end{array}$ \\
\hline liaw bagasse & 84.2 & 58.0 & 11.3 & 5.4 & 1.6 & 31.9 \\
Alkali-treated hagasse & 93.2 & 75.6 & 12.0 & 0.6 & 0.7 & 51.1 \\
liaw-bagasse ration & 42.1 & 25.8 & 7.2 & 2.2 & - & 52.0 \\
Treated-bagasse ration & 41.4 & 29.6 & 4.3 & - & - & 66.1 \\
\hline
\end{tabular}


vs. 51.1). The two complete rations were nearly alike in NDF content. Though the treated-bagasse ration contained more ADF, the chemical treatment removed lignin from this ration. The estimated digestibilitics (table 4) agree rather well with the in vivo values (table 3), viz., 52.0 and 55.7 for the raw bagasse and 66.1 and 68.6 for the treated-bagasse rations, respectively.

\section{SUMMARY}

Two successive digestibility trials were conducted employing four Holstein steers and 8-day total fecal collection periods. Both rations studied had the same basic formula, differing only in that one contained raw bagasse, and the other, bagasse treated in a 2-percent $\mathrm{NaOH}$ solution. Feed intakes were restricted to $97 \mathrm{~g}$. (about $\$ 3 \mathrm{~g}$. of DM) per kg. of metabolic body weight.

The mean apparent digestion coefficients determined in the treatedbagasse and raw-bagasse rations, respectively, were as follows: DM, 68.6 and 55.7; OM, 76.1 and 62.0; CP, 79.6 and 71.0; EE, 86.4 and 83.0; CF, 67.9 and 37.5 ; NFE, 77.6 and 64.6 ; TDN, 67.4 and 55.8; and calories, 74.0 and 58.9. The former ration contained 2.78 and the latter 2.27 Mcal. of DE per kg. of DM. Excluding EE, all of these mean differences between rations were statistically significant ; those for $\mathrm{OM}, \mathrm{CF}, \mathrm{TDN}$ and calories at $P<.01$, and those for DM, CP, NFE and DE at $P<.05$.

Single samples of alkali-treated and raw bagasse were found to contain the following percentages: neutral-detergent fiber, 93.2 and 84.2 ; aciddetergent fiber, 75.6 and 58.0; lignin, 12.0 and 11.3; silica, 0.6 and 5.4; and in vitro DM digestibility, 51.1 and 31.9. The latter criterion was found to be 66.1 and 52.0 in single samples of the complete rations containing treated and raw bagasse, respectively.

\section{RESUMEN}

Se efectuaron dos pruebas sucesivas de digestibilidad con cuatro novillos Holstein castrados, recogiéndose las heces fecales por completo durante períodos consecutivos de 8 días. Ambas raciones contenian la siguiente fórmula: maíz en grano molido, 18.45 por ciento; bagazo seco molido, 40.00 ; harina de atún, 10.00 ; urea, 2.50 ; fosfato mono- y dicálcico, 1.00; sal, 1.00; y suplemento vitamínico (A-D-E), 0.05. Las dos raciones diferían en que una incluía bagazo crudo, y la otra, bagazo tratado con una solución de $\mathrm{NaOH}$ al 2 por ciento. El consumo de las raciones se limitó a $97 \mathrm{~g}$. (unos $83 \mathrm{~g}$. de materia seca) por $\mathrm{kg}$. de peso metabólico.

Se determinaron los siguientes coeficientes de digestibilidad promedio para la ración con bagazo tratado y la ración con bagazo crudo, respectivamente: materia seca, 68.6 y 55.7; materia orgánica, 76.1 y 62.0 ; proteína bruta, 79.6 y 71.0 ; extracto etéreo, 86.+ y 83.0; fibra bruta, 67.9 y 37.5 ; ext racto no azoado, 77.6 y 64.4 ; mutrimentos digeribles totales, $\mathbf{1 7} .4$ y 55.8 ; y calorías, 74.0 y 58.9 . La primera ración contenia 2.78 y la segunda $2.27 \mathrm{Meal}$. de energía digerible por $\mathrm{kg}$. de materia seca. Excluyendo el 
extracto etéreo, todas estas diferencias promedio entre las dos raciones resultaron significativas estadísticamente: Las de materia orgánica, fibra cruda, nutrimentos digeribles totales y calorias tenian una probabilidad de $P<.01$, y las de materia seca, proteína bruta, extracto no azoado y energía digerible, $P<.05$.

En las únicas muestras que se tomaron del bagazo tratado y del bagazo crudo se encontraron los siguientes porcentajes de componentes, respectivamente: fibra detergente neutra, 93.2 y 84.2; fibra detergente ácida, 75.6 y 58.0; lignina, 12.0 y 11.3 ; sílice, 0.6 y $5.4 ; \mathrm{y}$ digestibilidad de la materia seca in vitro, 51.1 y 31.9 . Este último factor dio el 66.1 y el 52.0 por ciento al determinarse en muestras únicas de las raciones completas de bagazo tratado y bagazo crudo, respectivamente.

\section{LITERATURE CITED}

1. Association of Official Agricultural Chemists (A.O.A.C.), Official Methods of Analysis, 9th ed. Washington, D.C., 1960.

2. Crampton, E. W. and Harris, L. E., Applied Animal Nutrition, 2nd ed., W. H. Freeman and Co., San Francisco, Calif., pp. 47, 1969.

3. Kleiber, M., Metabolic body size, in proceedings of the 3rd Symposium on Energy Metabolism, Troon, Scotland, Academic Press, New York, N.Y., pp. 427-35, 1965.

4. Klopfenstein, T. and Woods, W., Sodium and potassium hydroxide treatment of wheat straw and corn cobs, abs., J. Anim. Sci. 31: 246, 1970.

5. Mellenberger, R. W., Satter, L. D., Millet, M. A. and Baker, A. J., Digestion of aspen, alkali-treated aspen, and bark by goats, J. Anim. Sci. 32: 756-63, 1971.

6. Parr Instrument Company, Oxygen Bomb Calorimetry and Combustion Methods, Tech. Man. 130, Moline, Ill., 1966.

7. Prieto, E. and Ranel, P. F., The digestibility of a bagasse complete ration in comparison with a conventional ration for dairy cows, J. Agr. Univ. P.R. 54 (3): 439-47, 1970.

8. Randel, P. F., Carrero, R., and Valencia, I., Estudio preliminar sobre el uso de bagazo tratado químicamente en raciones completas para vacas lecheras, Univ. P.R. Agr. Exp. Sta. Misc. Publ. 70, 1970.

0. Saxena, S. K., Donker, J. D., Otterby, D. E. and Good, A. L., Effect of alkali treatment of straw and source of nitrogen supplemented on dry matter and nitrogen utilization in ruminants, abs., J. Dairy Sci. 53: 680, 1970.

10. Tarkow, HI. and Feist, W., The superswollen state of wood, Tappi 51: 80, 1968 (from J. Anim. Sci. 32: 756-63, 1971).

11. Van Soest, P. J. and Moore, L. A., New chemical methods for analysis of forages for the purpose of predicting nutritive value. In Proceedings of the 9th International Grassland Congress, Sao Paulo, Braz., Sect. 1, Paper 424, pp. 739-42, 1965.

12. Van Soest, P. J., Wine, R. H., and Moore, L. A., Estimation of the true digestibility of forages by the in vitro digestion of cell walls. In Proceedings of the 10th International Grassland Congress, Helsinki, Finland, Sect. 2, Paper 20, pp. 438-41, 1966. 